\title{
A National Anthem for the North
}

By means of war commemoration, the consolidation of a political community, which is set in motion during a military conflict, can persist long thereafter. After the kingdom of Israel had been defeated by imperial powers and no longer possessed a native army with which to engage its enemies on the battlefield, the Song of Deborah could continue to unite the nation as a "mnemonic community." In what follows, we focus on this basic purpose of the song. Comparing it to parallels from the Bible as well as the ancient Aegean world and colonial America, I will endeavor to show how the song served as a "national anthem" for Northern communities after the fall of the kingdom of Israel in 722 BCE.

\section{MOBILIZING THE NATION'S MEMBERS}

The song's depiction of the nation's plurality and unity culminates in the composition of the central section, the "Catalogue of Tribes" (Judg. 5:I4-I 8), which identifies the combatants by tribe or region. This section is easy to isolate, and when it's removed, one notices a tight connection between the surrounding statements: Yhwh's people march down against/ with the mighty (v. I3), and the kings of Canaan come and fight (v. I9). Read together, these lines portray Israel as a people confronting Canaanite polities that are represented solely by monarchs. The Catalogue of Tribes in turn celebrates those who contributed to this war effort, while chiding others for failing to take part.

I See Eviatar Zerubavel, "Social Memories: Steps to a Sociology of the Past," Qualitative Sociology, I9 (1996), 283-299. 
Throughout the song, those who take part - who "march down to the gates" - are called variously "the people of Yhwh," those "who love him," "those who offer themselves freely," etc. Positioned right before the descriptions of the actual engagement, the Catalogue of Tribes uses proper names to identify the groups that participate:

From Ephraim came they whose roots are in Amalek;

And after you Benjamin with your kin;

From Machir came down leaders,

From Zebulun such as hold the marshal's staff.

And Issachar's chiefs were with Deborah;

As Barak, so was Issachar,

Rushing after him into the valley.

Judg. 5:I4-I 5 a

The five names listed here - Ephraim, Benjamin, Machir, Zebulun, and Issachar - correspond to tribes or regions. By naming them, the song commemorates their contributions and thereby declares that they deserve an honored place in the history of the nation. The two last-named participants, Zebulun and Naphtali, are the same tribes that join Barak in the prose version of chapter 4 . Given the special place they occupy in that chapter, it's not surprising that their contribution is singled out here:

Zebulun is a people that spurned its soul to die, Naphtali, on the open heights.

Judg. 5:18

The expression "spurned its soul (to die)" appears frequently in later Hebrew literature (e.g., in the official "Prayer of Remembrance for War Casualties" of the Israeli Defense Forces) to describe courageous selfsacrifice in battle. ${ }^{2}$ Throughout the Hebrew scriptures, death in battle is, with very few exceptions, a consequence of sin; likewise, victories are astonishingly devoid of any casualties in Israel's ranks. One of the principal reasons for this curious fact is, as I argue elsewhere, a traumatic experience with radical politics: Many were willing to resist the encroachment of imperial armies at great expense, rejecting Jeremiah's ethos of "put your necks under Babylon's yoke ... and live!" (Jer. 27:I2). By risking all for the sake of territorial sovereignty, their politics brought only more pain and suffering on their communities. In opposition to these

2 The word hêrēpp (spurned) is often synonymous with yôreh, (to shoot/throw/cast off), so a more precise translation might be "cast off its soul to die." The expression may be intentionally ambiguous, especially given the repetition of Zebulun and its position after the chiding of the tribes who shirked their wartime duties. 
insurgent factions and their cult of martyrdom, the biblical scribes went to great lengths to avoid one of the basic rituals of statehood: the heroizing, memorializing, and sanctifying of the war dead. ${ }^{3}$

In between these lines, the catalogue identifies four tribes that failed to heed the call to arms:

Among the clans of Reuben

Were prolonged contemplations of the heart.

Why did you stay among the sheepfolds

And listen as they piped for the flocks?

Among the clans of Reuben

Were prolonged contemplations of the heart!

Gilead tarried beyond the Jordan;

And Dan - why did he linger by the ships?

Asher remained at the seacoast

And tarried at his landings.

Judg. 5:I $5 \mathrm{~b}-\mathrm{I} 7$

The tribes that are clearly included among the belligerents are described with verbs of action. Most often, they are said to have "descended" $(y-r-d)$. In this way, the song identifies those who fight as highland dwellers who go down to battle in the Jezreel Valley. In contrast, the nonparticipants are portrayed in states of nonmovement, inactivity, passivity, and even tranquility. The transition to these verbs of inaction, and their variety, is pronounced; the specific verbs are "stay" $(y$-š- $b)$, "dwell" $(\check{s}$ $k-n)$, and "reside" $(g-w-r) .{ }^{4}$

In Numbers 32, which we studied in Part II, the verb $y$-š- $b$ is the operative term in Moses's censure of the Transjordanian tribes of Reuben and Gad for not contributing to the Cisjordanian war effort: "Shall your brothers/comrades go to war while you stay $(y$-š- $b)$ here?" (v. 6). Reuben and Gad desire to "stay" in the Transjordan, rather than cross over and fight in the Cisjordan, since the rich pasturelands of the Gilead were well suited to their large herds (vv. I-5). The Song of Deborah indicts the tribe of Reuben (in interrogatory form, like Num. 32:6) for staying in the safety of their sheepfolds and lazily listening to their herds rather than rising up to heed the call to arms.

${ }^{3}$ I show how the Hebrew Bible, in contrast to the New Testament, rejects heroic (substitutionary) death and martyrdom in my article "Making a Name."

${ }^{4}$ Against proposals that this section describes the tribes contributing to the war effort, rather than shirking their duties, see Jacob L. Wright, "War Commemoration and the Interpretation of Judges 5:I 5 b-I 7," Vetus Testamentum, 6I (20II), 505-52I. 
That this use of $y$-š- $b$ is formal or technical is suggested by the strange "law and ordinance" instituted by David: "For the share (of booty) of the one who goes down $(y-r-d)$ to war shall be the same as the one who stays $(y-s ̌-b)$ with the baggage; they shall share (the spoils) together" (I Sam. 30:24). Here, $y$-š- $b$ is employed in a similar sense to Numbers 32:6 and the song; these texts refer, however, to those who shirk their military obligations rather than performing a logistical-support function. ${ }^{5}$

The Catalogue of Tribes has much in common with Jacob's deathbed blessings for his sons in Genesis 49. For example, its descriptions of Asher and Dan are similar to the patriarch's statement about Zebulun (Gen. 49:13). ${ }^{6}$ Immediately thereafter, Jacob speaks of Issachar lying "among the flocks/baggage," a rare expression found only in Psalm 68, which is closely related to the song (see the discussion in Chapter II), and in the song itself, where it is applied to Reuben. In Genesis 49, Reuben is the first to be mentioned: Jacob condemns his actions and prophesies his end. Likewise, in the song, Reuben leads the list of the reproached tribes.

These and other observations bespeak the likelihood that the scribes who expanded the song drew on several lines from Jacob's blessings and applied them to the nonparticipants with a new twist. Whereas Genesis promotes pacifistic ideals, the book of Judges, in keeping with the very different ethos set forth in the exodus-conquest account, demonstrates the need for bellicose interactions with Israel's neighbors. ${ }^{7}$ Thus, Genesis 49 reproaches Simeon, Levi, and Benjamin for their unbridled violence and bellicosity; in contrast, the song uses the acclamations of quietude and idyllic passivity in Genesis 49 to upbraid several tribes for failing to rise up and mobilize for Israel's war effort. ${ }^{8}$

5 The law is part of a supplement to the account (I Sam. 3 I:9b-IO, 2I-25; see also I Sam. 25:I3). It differs from the Priestly practice of dividing up the spoils unequally between those who go out to battle and the rest of the congregation (Num. 31:25-30). All these texts reflect larger concerns over the issues posed by service and reward: If fighting is the basis for belonging, what about those who cannot fight but contribute in other ways? The issue is thus about more than the particular scenario portrayed in these texts.

6 The song presents Issachar and Zebulun in the same sequence. Notice also how "scepter" and "ruler" are paralleled in Judges 5:I4 and Genesis 49:IO.

7 On these differences between Genesis and the exodus-conquest account, see Chapters 2 and Io. On the issues posed by, and the biblical polemics directed at, the Transjordanian tribes, see Part II.

${ }^{8}$ Ephraim's "root is in Amalek" (cf. Judg. I 2:I 5). This statement associates Ephraim with a militant people. In contrast, Reuben is listening to the whistles of/to the herds (rather than the call to battle), Dan is resting in his ships (or "at ease"), etc. 


\section{CENSURE OF TRANSJORDANIAN COMMUNITIES}

One of the most basic themes of Judges is Israel's unity and disunity as a people. While the book of Joshua depicts a high point in the nation's past by portraying its members joining together to conquer Canaan, the book of Judges tells how, after the death of Joshua, this unity dissolves, never to be reestablished. The only time the tribes assemble and unite for action is when they wage war against their own members, and even then some do not take part (see Judg. 2I:5-I4).

In keeping with Judges' concern with Israel's unity, several passages in the book depict Israel's tribes providing, failing to provide, or being jealous that they were not asked to provide, military assistance. Many of these texts relate to Ephraim and Benjamin, tribes that occupied Israel's core territory. Thus, a Benjaminite named Ehud petitions Ephraim to assist him against Moab (3:27), and in the same way, Gideon calls on Ephraim for help (7:24-25). As the narrative progresses, the depiction of Benjamin and Ephraim becomes gradually less favorable: The Ephraimites are angered that Gideon did not call on them earlier $(8: I-3)$. Later, they mobilize for war against Jephthah the Gileadite because, once again, they were not invited to participate (I2:I-3). In the final chapters of the book, a couple of Ephraimite individuals commit (shocking) crimes, and war is declared on Benjamin (chaps. 20-2I). Notably, in the Song of Deborah, Ephraim and Benjamin are praised for being the first tribes to "come down" for battle (5:14). This is just what we would expect given the gradual transition of the book's narrative from a positive to a negative tenor in the depiction of these tribes.

The members most excoriated in the song are the Transjordanian tribes of Reuben and Gilead; no fewer than six cola - with the indicting question surrounded by an inclusio - are devoted to Reuben. The censure of communities from the eastern side of Jordan is once again consistent with the larger narrative of Judges. In the immediately following chapters of the book, Gideon and his 300 famished men cross the Jordan in pursuit of the Midianite armies. He begs the inhabitants of Succoth for a few loaves of bread, yet his request is sharply rejected, with a telling rhetorical question: "Are [the enemy leaders] already in your hands that we should give bread to your troops?" (8:6). Gideon then petitions the city of Penuel and receives the same response. These two Transjordanian communities would be willing to supply victuals for Gideon and his men, but only 
after they prove themselves to be the victors; because they were unwilling to contribute to the Cisjordanian war effort until victory had been achieved, they are subjected to harsh sanctions. ${ }^{9}$ The book's censure of Succoth and Penuel is remarkable given that these cities figure prominently, and favorably, in the narrative of Jacob's wanderings constructed in Genesis (see Gen. 32:17, 24-32, 33:17).

Several other texts in Judges cast aspersions on the Transjordanians. The account of Jephthah (chaps. IO-I2) depicts the inhabitants of Gilead and its leadership as self-absorbed and foolish. As the son of a harlot, Jephthah is disinherited and becomes a leader of a marauding band out in the backcountry of Tob. Later, the elders of Gilead bring him back, but only because they need someone who can fight their wars with the neighboring Ammonites. Jephthah acquiesces on the condition that they make him their leader, and later he must sacrifice his daughter to Yhwh as compensation for his triumph. The account concludes with him gathering all his men to do battle against members of Israel, slaying 42,000 inhabitants of Ephraim. This censure of Jephthah and Gilead is echoed in the last chapter of the book, where the city of Jabesh-Gilead ducks its wartime duties and is punished with the extermination of all its citizens (2I:5-I4).

The same failure to support a pan-Israelite war effort is the grievance brought against the Transjordanian communities in the Song of Deborah. Moreover, the way the song associates Gilead with those who cowardly dodge their military duties may be compared to the words Gideon utters when he musters out all the lily-livered troops: "Whoever is fearful and trembling, let him return home, flying like a bird from Mount Gilead" (7:3). ${ }^{\text {Io }}$

The book of Judges is not alone in this respect. As we saw in Part II, a wide range of biblical texts address a question posed by the Transjordanian communities. If the Jordan marks the border of the Promised Land, what is the status of the territories on the east bank of the river? Many of the texts we looked at address this question in relation

9 Their refusal to provide alimentary succor for the troops - a common type of wartime contribution (see discussion in Part I) - is comparable to a failure to send one's own troops as reinforcements. Rashi reads the reference to Reuben in the song in light of this text: its members dwelt/stayed on the sidelines, waiting to hear the bleating of the flocks as an indication of who had won and who had lost. In keeping with an established exegetical tradition, Rashi treats the problem posed by the larger number of tribes who fight in the song by interpreting it as referring to past history (e.g., Ephraim=Joshua, or Machir relates to Deut. 3:4, I4) as well as to Deborah's prophecy of future events (e.g., Benjamin=Saul).

Io Birds are frequently portrayed as timid, fluttering creatures eager to flee to the mountains (see, e.g., Hosea I I: I I; Ps. I I:I). 
to wartime contributions. Some texts censure the Transjordanian communities for attempting to shirk their military duties, while others respond to these accusations, claiming that the Transjordanians spearheaded the offensive when Israel crossed the Jordan and took possession of the Promised Land.

Against the backdrop of these numerous texts, it's all the more significant that the Song of Deborah contains several strophes that accuse the Transjordanian tribes of forsaking their wartime obligations to the nation. Yet there is a difference between the song and the texts reviewed above: rather than attempting to impugn the memory of the Transjordanian communities, the indictment more likely affirms their membership by implying that they have the same obligation as the Cisjordanian tribes. It's noteworthy that Dan and Asher are the other two tribes that the song censures for dodging their duties. The land allocated to these tribes does not belong to the core territory of Israel and was rarely under its hegemony. Israelites were a hill-country people, and this fact accounts for the scarcity of references to ships and seacoast life in the Bible. In the song, all the territories/tribes that "go down" to battle are located in the central hill country and the Jezreel Valley, regions that constitute the central realm of the kingdom. ${ }^{\text {II }}$ Thus, while the prose version of the Deborah-Barak account (Judg. 4) focuses on the contributions of Zebulun and Naphtali, the song commemorates Ephraim and Benjamin as the first tribes to follow Deborah. By chiding communities on the periphery (on the coasts, in the North, and across the Jordan) for failing to demonstrate their belonging, it invites these outlying communities to join the core and demonstrate that they belong to the people who eagerly volunteer themselves for the cause of Yhwh and Deborah. ${ }^{\text {I2 }}$

\section{JUDAH'S ABSENCE}

One of the most remarkable features of the song is that it commemorates the contributions of only ten tribes, not twelve as we would expect. ${ }^{\text {I3 }}$

${ }^{\text {II }}$ For a discussion of early highland polities and the expansion of their borders, see Finkelstein, Forgotten Kingdom.

I2 Some scholars view the polemics against nonparticipation as the song's original and primary purpose (see, e.g., G. T. K. Wong, "Song of Deborah as Polemic," Biblica, 88 (2007), I-22). The evidence for the secondary quality of the Catalogue of Tribes gainsays this view.

I3 The notion of twelve Israelite tribes is a late one. Most scholars assign it to the Priestly source, which originated in the late monarchic or the exilic period. If so, the 
What's more, two of the ten names, Gilead and Machir, do not appear in the canonical tribal registers. With respect to Machir, many texts locate this tribe in the Transjordan, identifying it with either the name of Gilead's father or the clan that conquers Gilead. ${ }^{\mathrm{I}}{ }^{4}$ The rich region of Gilead is ascribed by many biblical texts to Gad. While Gilead is censured in the song, Machir is praised - namely, for sending troops down to the battle. This movement is easiest to understand if Machir represents not an eastern territory but rather the large region in the central hill country known as Manasseh. Not only does the song fail to mention Manasseh; it also refers to Machir right after Ephraim and Benjamin in the south and right before Zebulun and Issachar in the north - precisely the Cisjordanian region identified elsewhere as Manasseh. Not surprisingly, a number of biblical texts identify Manasseh as the father of Machir.

But what about the absence of Judah? All the tribes/regions that do not participate in the battle are on the outermost margins of Israel's core territory, located either across the Jordan or on the northern periphery. Written from the perspective of Ephraim and Benjamin, the song should either report that Judah took part in the battle or rebuke it for failing to do so. The indictment for shirking duties is, as noted, an implicit affirmation of membership in the nation, but the song issues no such indictment against Judah.

The significance of Judah's absence would be difficult to overstate. Much of the biblical corpus originated in the North, in the context of the kingdom of Israel (Samaria) as well as during the centuries after its destruction in 722 BCE. But the biblical corpus wouldn't exist - or at least it would look very different - were it not for Southern scribes who expanded and shaped it during the final century of the kingdom of Judah and then after foreign empires conquered this kingdom in $587 \mathrm{BCE}$.

The activity of these Southern scribes is the reason why the tribe of Judah figures so prominently in biblical literature. In the book of Judges, Judah is the first tribe chosen by Yhwh to "go up" to conquer the land (chap. I), and it's the first tribe to produce a "savior" who delivers Israel from its enemies (3:7-II). These passages were likely added in the book's final compositional stages. If their authors had been involved in the composition of the song, we would expect Judah to have been portrayed as marching at the front of the tribes who mobilize for war, yet the song

unconventional constellation of the tribes in the catalogue indicates that it likely predates the postexilic period.

${ }^{14}$ See, e.g., Num. 26:29, 27:I, 32:39-40. 
has nothing whatsoever to say about Judah, assigning the leading role to Ephraim and Benjamin.

What possibly motivated the omission was, I suggest, the move by Judah, and above all the Davidic dynasty that ruled Judah, to lay claim to Israel's cultural heritage after the conquest of Samaria in 722 BCE. In reaction to this move, scribes from the erstwhile kingdom of Israel appear to have collected and composed a number of texts that envision Israel as a people without a king at its center. Their most important literary production was the exodus-conquest account, and if the earliest iteration of the Judges narrative was composed as a continuation of that account, it makes sense that the Song of Deborah articulates a national identity for Israel that includes neither Judah or a monarchy. ${ }^{{ }^{5}}$

A testimony to the kind of statist ideology that developed in Judah is found in Psalm 78. ${ }^{16}$ This psalm represents the antithesis of the song. Thus, it assigns an indispensable role to a monarch: "[Yhwh] chose David, his servant, and took him from the sheepfolds. He brought him from the nursing ewes to tend his people Jacob, Israel, his very own ..." (vv. 70-72). Likewise, the perspective in the psalm is explicitly antiNorthern: "[Yhwh] rejected the clan of Joseph; he did not choose the tribe of Ephraim. He chose instead the tribe of Judah, Mount Zion, which he loved" (v. 67). Like the Song of Deborah, the psalm uses war commemoration to formulate its polemics: "The Ephraimites, armed with the bow, turned back on the day of battle ..." (v. 9). The psalm continues: "They did not keep God's covenant, and refused to walk according to his law. They forgot what he had done ..." (vv. IO-II). This late Judean broadside against the North conjoins memories of military service with fidelity to the Torah, which is similar to what we observed in Part II with respect to the Narrative of the Transjordanian Tribes.

\section{THE CURSE OF MEROZ}

The Catalogue of Tribes evinces parallels not only with other biblical texts, but also with war commemoration in the Aegean world. Thus, the so-called Catalogue of Ships transmitted in Homer's Iliad negotiates belonging by naming the contingents and their leaders who contributed

I5 For alternative theories on Judah's absence, see Fleming, Legacy of Israel, 58-7I.

${ }^{16}$ On the dating and purpose of the psalm, see Markus Witte, "History and Historiography

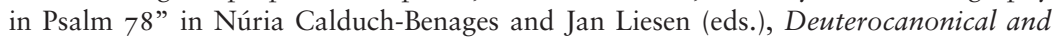
Cognate Literature: Yearbook 2006 (Berlin: De Gruyter, 2006), 2 I-42. 
to a momentous collective war effort situated in the shadows of time. ${ }^{17}$ It also includes descriptive epithets of the territories and clans, similar to what we witness in Genesis 49, Deuteronomy 32, and the Song of Deborah. Most experts agree that this Homeric text has been supplemented variously with the names of new contributors and that some participants may have been deleted as a way of criticizing these communities. By stating exactly how many ships each land sent, the catalogue ranks the level of each participant's contribution. For example:

Men from Tricca, rocky Ithome, Oechalia, city of Eurytus, the Oechalian, were commanded by two sons of Asclepius, skilled healers, Machaon and Podaleirus. They brought thirty hollow ships with them

$$
\text { Iliad 2.729-809 }
$$

Other strophes name the land that sent the best horses $(2.76 \mathrm{I}-765)$ or the best warriors (2.767-768). The catalogue also notes nonparticipation: "But their minds weren't set / on the grim clash of war. They had no one to lead them" (2.76I-762). Later, we read that these same troops "stayed behind by their ships" and "amused themselves" in various ways (2.77 I779; cf. Judg. 5:I6-I7). ${ }^{18}$

By imagining the nation's territories as discrete and circumscribed tribal units, the Catalogue of Tribes from the Song of Deborah could treat the problem of "the one and the many" in Israel's political history: e pluribus unum. The counterpart to this unification is exclusion, as we witness in the case of Meroz. This is the only time in the Bible where the name Meroz appears. Whatever group this name represents, the song clearly does not extend membership to its members:

Curse Meroz, says the angel of Yhwh,

Curse bitterly its inhabitants,

Because they did not come to the help of Yhwh,

To the help of Yhwh with/against mighty warriors.

Judg. $5: 23$

Similar maledictions and sanctions are known from the Aegean world. For example, the city Thebes was reluctant to join the Hellenic alliance and later fought on the Persian side (even though 400 Theban hoplites were

17 2.494-759; see also the Trojan "Battle Order" in 2.8I6-877. On this text, see Edzard Visser, Homers Katalog der Schiffe (Stuttgart: B. G. Teubner, I997).

${ }^{18}$ See also the Trojan "Battle Order" in $2.816-877$ and the description of warriors in 3.I60-244, as well as Niditch, Judges: A Commentary, 79. 
supposed to have fought bravely against the Persians at Thermopylae). As a result, the city was severely penalized and almost eliminated from the Delphic amphictyony. ${ }^{19}$

I've argued that the song doesn't exclude from the national fold several tribes on Israel's periphery when it scolds them for failing to contribute to Deborah's war effort; to the contrary, it affirms their belonging among the people of Israel and exhorts them to demonstrate this belonging through their actions in the present. Had the authors of our song wished to sever ties with other tribes, we would expect them to have pronounced a curse upon them as they did on Meroz. That the song does not do so is likely because the scribes who repurposed the older hymn wanted to encourage marginal communities to think of themselves as part of Israel and to conduct themselves accordingly.

Why then is Meroz execrated? Scholars have offered a range of explanations: Israel expected Meroz to cut off the enemy when the latter retreated, but Meroz did not do so and was therefore harshly cursed. Or Meroz was in alliance with Israel but joined "the Canaanites" during this battle. According to another suggestion, economic reasons militated against the participation of the other tribes that did not participate, whereas Meroz lacked a legitimate excuse. ${ }^{20}$

These suggestions are, however, based on little more than speculation. As we saw in our reconstruction, the insertion of the Jael material juxtaposes "most blessed of women is Jael" with "Curse Meroz ... for they did not come to the help of Yhwh," and before the Jael material was inserted into the older hymn, the imprecation would have stood right before "So may all your enemies perish, O Yhwh!" in the final strophe. The authors of the hymn may have chosen an obscure name, or even invented one, in order to illustrate the point of the curse: those who conduct themselves as Meroz did, failing to "come to the help of Yhwh," however such "help" is understood, will be punished with total oblivion.

\section{MEROZ AND THE AMERICAN WAR OF INDEPENDENCE}

In I777, a year after the American colonies declared their independence from Great Britain, a Presbyterian minister named Nathaniel Whitaker,

19 In the Conclusions, we treat other examples of Aegean war commemoration that emerged in the wake of the Persian Wars.

${ }^{20}$ On the identification of Meroz, see Erasmus Gaß, Die Ortsnamen des Richterbuches in historischer und redaktioneller Perspektive (Wiesbaden: Harrassowitz, 2005). 
pastor of the Third Church of Salem, Massachusetts (the "Tabernacle"), delivered a sermon on the curse of Meroz entitled "Antidote Against Toryism." The transcript was widely circulated both during and after the Revolutionary War and was republished a year before the American Civil War. ${ }^{2 \mathrm{I}}$ The sermon offers a graphic illustration from recent reception history of the song's political potential. What makes the sermon especially worthy of our attention is the way it, like the song, combines antimonarchic sentiment with an emphasis on volunteerism.

According to Whitaker, the Song of Deborah provides biblical justification for limiting membership and privileges in the American colonies to those individuals and communities who readily contributed to the war effort against King George of England. Applying the curse of Meroz to those who remain loyal to the British throne, the Presbyterian preacher begins by observing that:

our struggle with Great Britain is very similar to that of Israel and Jabin. As they had, so have we been long oppressed by a power that never had any equitable right to our land, or to rule over us, but by our own consent, and agreeably to a solemn compact.... Therefore, if it was their duty to fight for the recovery of freedom, it must likewise be ours. And to neglect this, when called to it by the public voice, will expose us to the curse of Meroz.

Asserting that America's war is as equally legitimate and divinely authorized as the war that Israel initiated against the Canaanite king, Whitaker goes on to declare that:

those who are indolent, and backward to take up arms and exert themselves in the service of their country, in order to recover and secure their freedom, when called thereto by the public voice, are highly criminal in the sight of God and man.

Contributions to the war effort consist of more than just bearing arms; all kinds of exertion for the public good are demanded. Men and women, young and old, are called upon to give liberally of their time and substance. Pastors should preach to encourage the public, while parents should exhort their children to do their part. Everyone can participate in various kinds of manufacturing activities and services essential to the success of the American forces.

${ }^{21}$ Quotations are drawn from Frank Moore (ed.), The Patriot Preachers of the American Revolution: With Biographical Sketches (New York: Charles T. Evans, I862). The sermon was reprinted in I8I I by Poole \& Palfray in Salem. See now James Byrd's Sacred Scripture, Sacred War: The Bible and the American Revolution (New York: Oxford University Press, 20I3), chap. 3. 
Whitaker's sermon contains some of the most eloquent early American rhetoric in defense of "republican civic virtue" - the willingness to forego personal pursuits and private concerns for the sake of the common good. Here's a representative excerpt:

This was the crisis when their all lay at stake. They well knew that their brethren ... were groaning under cruel bondage. But as selfishness renders people callous and unfeeling to the distresses of others, so they were easy and satisfied to see their brethren tortured by the unrelenting hand of oppression, if so be they might sleep in a whole skin. They were contented that others should go forth and endure the hardships of war, but refused to engage in the work, or bear any part of the burden with them ....

Whitaker is describing here both the inhabitants of Meroz and the Tories of his own day. In contrast to outright betrayals benefiting the enemy or active efforts to discourage the nation's wartime resolves, the sin of Meroz is that they simply failed to do their part:

The crime they are charged with, is not their aiding, assisting, or furnishing the enemy, or holding a secret correspondence with, or taking up arms to help them; they are not charged as laying plots to circumvent the rest, or striving to discourage their neighbors from going to war, or as terrifying others with descriptions of their irresistible power of Jabin's nine hundred chariots of iron and the like. No, the inhabitants of Meroz were innocent people compared to these; they were only negatively wicked, they only failed in their duty; they did not arm to recover their liberties when wrested from them by the hand of tyranny. This is all the fault charged on them, yet for this they incurred the fearful curse in my text.

According to Whitaker's exposition, God requires a nation, like ancient Israel and its successor America, to treat those who will not join them in their cause for liberty as "open enemies" and to "reject them as unworthy of the privileges of society." The song articulates a basic criterion of affiliation to the political community, one that restricts privileges of membership to those who make sacrifices on behalf of the nation in arms.

A curse is something more than wishing ill to a person. It implies a separating him to some evil, or punishment. The command in my text therefore required Israel to separate the inhabitants of Meroz from some temporal good the rest of Israel enjoyed, and inflict on them some severe punishment ....

Those who dodged their duty must not be allowed to enjoy a place of honor in the government; instead, they should be deprived of "that delightful freedom and liberty Israel had regained from the tyranny of Jabin." At one point, Whitaker calls for the enslavement of these dodgers: 
As these wretches discovered their servile temper in refusing to exert themselves for the recovery of their liberty, why should they not be condemned to the slavery they chose?

Later, he refers to more mild punishments, such as taxation without representation. In conclusion, the Massachusetts minister makes it clear that the punishment of Meroz is an enduring, if not timeless, moral duty, not confined to a period of military conflict. Indeed, it must be a fundamental feature of the ongoing program of reform that paves the way to the nation's happiness:

[W]e shall then see our councils filled with men inspired with wisdom to know what Israel ought to do; our arms victorious and triumphant; the inhabitants of Meroz justly punished; peace, liberty and safety restored; the rod of tyranny broken; pure and undefiled religion prevailing, and the voice of joy and gladness echoing round our land. May God hasten the happy, happy day!

Whitaker's sermon demonstrates the song's potential to mobilize a political community around (republican) ideals of communal volunteerism, without looking to a monarch to define its identity. But there are important differences to be noted between the song itself and Whitaker's appropriation of it for the American colonial context.

In Chapter II, we observed how during World War II, the US armed forces appealed to a "Judeo-Christian tradition" in an effort to unite the nation and its troops, and we noted that the formation of the song - and by extension, much of the biblical corpus - was likewise propelled and sustained by concerns to bring together rival communities as one people. The difference is that the biblical project is not about mobilizing a nation for war, but creating a nation in the aftermath of defeat.

Similarly, Whitaker applied the song to a war of liberation and emergent statehood; however, we've seen that the song seeks to consolidate a nation in the wake of defeat and the demise of statehood. In focusing on one strophe of the song (the curse of Meroz), Whitaker's exegetical sermon misses the overarching message of his biblical text: the song does not celebrate the victory of a nation-state; rather, it affirms that a nation (Israel) can exist without a state.

What is perhaps even more jarring than the way Whitaker adapts the song to the politics of statehood is the manner in which he masculinizes its contents: men are to do the fighting, while women are to support them from their family homes. His audience never learns that the song abolishes this gender binary, celebrating a "mother in Israel" alongside a woman 
who defies her husband's politics and deftly dispatches the enemy leader from her domestic confines. Indeed, the macho tenor of Whitaker's sermon helps us appreciate the song's revolutionary gender-bending agenda. In Chapter I3, we explore this important dimension of the song.

\section{A NATION WITHOUT A KING}

In interpreting the song as a "national anthem," I do not mean to suggest that it was performed in ancient Israel in the manner that, for instance, Americans sing "The Star-Spangled Banner." My point is rather that the intention driving the composition of this work anticipates the creation of modern anthems that began in the nineteen century. ${ }^{22}$

National anthems promote and celebrate symbols unifying the members of their political communities. Frequently, these anthems mimic military marches or relive a battle, summoning the nation's citizens to demonstrate their belonging through devotion and deed. While most contemporary anthems extol the country and the core values that bind its diverse populations (e.g., "La Marseillaise"), some have their origins in praise and supplications for monarchs (e.g., "God Save the Queen"). In intoning the hymn, the subjects pray collectively for their king's or queen's military success and long life, as the prosperity and security of the monarch presumably redound to their subjects' benefit.

While the Song of Deborah has many features in common with these anthems, the nation it imagines is not governed by a human king; he's been dethroned and his place assigned to a deity named Yhwh and to "a mother in Israel" named Deborah. Indomitable volunteerism, selfless sacrifice on the behalf of Yhwh and his people, and the courage to face fearsome opposition - these are the national virtues held high in this poetic monument.

The song imagines a nation consisting solely of Northern communities, and it likely emerged among scribes from these communities who were writing shortly before and especially after the downfall of their kingdom

22 See Christopher Kelen, Anthem Quality: National Songs: A Theoretical Survey (Bristol: Intellect, 20I4). One of these anthems is "The Battle Hymn of the Republic." Written by Julia Ward Howe, an abolitionist and supporter of the Union cause during the American Civil War, and performed as a war march and in protests against antebellum slavery, the song draws deeply on biblical sources, as Scott C. Ryan demonstrates; see "God in Conflict: Images of the Divine Warrior in Ancient Jewish and Early Christian Texts," The Bible and Interpretation website, https://bibleinterp.arizona.edu/articles/god-conflict -images-divine-warrior-ancient-jewish-and-early-christian-texts [20I9]. 
in 722 BCE. For more than a century, the Southern kingdom managed to maintain its existence, and, during this time, the Davidic kings enthroned in Jerusalem urged Northern communities to recognize them as their divinely appointed rulers. ${ }^{23}$ As a memorial to the battle fought against the kings of Canaan during the birth of the nation, the song responds to, and repudiates, these political overtures, conveying a momentous message to its vanquished audience: Long before the reigns of their kings, Northern communities had come together from far and wide and collectively surmounted formidable challenges, and they could do so again now that their kings had been exiled.

Voluntary service and sacrifice are the basic expressions of national belonging. After all, a nation exists only to the extent that a group continues to will it through collective action. Such is what the Breton philosopher and Semiticist Ernest Renan meant by "daily plebiscite" when, in I 882 at the Sorbonne, he delivered his influential response to the question "What is a Nation?"

A nation is therefore a large-scale solidarity, constituted by the feeling [le sentiment] of the sacrifices that one has made in the past and of those that one is prepared to make in the future. It presupposes a past; it is summarized, however, in the present by a tangible fact, namely, consent, the clearly expressed desire to continue a common life. A nation's existence is, if you will pardon the metaphor, a daily referendum, just as an individual's existence is a perpetual affirmation of life. $^{24}$

Renan here underscores the voluntary nature of the nation. While the nation presupposes a past and therefore a narrative (see Part II), what is most important is the fact that and the manner in which its members translate past sacrifices into a shared desire to continue a common life.

23 These claims are most pronounced in the David stories in which Saul represents the Northern monarchy. Thus, in 2 Samuel 5:I-3, all the Northern tribes come to David at Hebron and recognize his royal authority: "Long before now, when Saul was king over us, it was you who led Israel in war; and Yhwh said to you: 'You shall shepherd my people Israel; you shall be ruler of Israel." In their words, we can hear the Davidic kings beckoning Northern communities to accept their rule now that Saul is dead (i.e., now that the Northern kingdom has fallen). See Wright, David, King of Israel, chap. 3.

${ }^{24}$ An English translation and the original French version are available online at www .nationalismproject.org/what/renan.htm. The language of "feeling" and "sacrifices" has its origins in European Romanticism. 